\title{
Income Inequality and Regional Index of Financial Inclusion For Islamic Bank in Indonesia
}

\author{
Prastowo $^{1}$, Diyah Putriani ${ }^{2}$
}

\begin{abstract}
This research is proposed to measure financial inclusion index in 2 dimensions (2D-FII) in Indonesia Islamic banks. This research contributes to the measurement 2D-FII at the regional level in Indonesia. The analysis of crosssection data from 33 provinces in Indonesia between 2014 and 2015 shows that the value of FII in Islamic banking in Indonesia is still low. Previous works show one of the determinants on increasing inequality in any country is limited access to the financial sector, especially for low-income household (Akimov, Wijeweera, and Dollery 2006; Kenourgios and Samitas 2007; Levine 2003; D. Park and Shin 2015). Thus, the low level of FII in Indonesia perhaps is caused by inequality of income. Therefore, this research recommends policymaker to have more concern on poverty alleviation program and open new Islamic banks branches at the regional level.
\end{abstract}

Keywords: 2 Dimension - Financial Inclusion Index (2D-FII), income inequality, Poverty alleviation, Islamic banks

\begin{abstract}
Abstrak. Penelitian ini bertujuan untuk mengukur indeks inklusi keuangan pada 2 dimensi (2D-FII) pada bank-bank syariah di Indonesia. Secara umum, penelitian ini berkontribusi pada pengukuran 2D-FII di tingkat regional Indonesia. Analisis terhadap data dari 33 provinsi di Indonesia antara tahun 2014-2015 menunjukkan bahwa nilai FII pada perbankan syariah di Indonesia masih rendah. Kajian-kajian terdahulu menunjukkan bahwa salah satu penentu peningkatan ketimpangan di berbagai negara adalah akibat akses terhadap sector keuangan yang masih terbatas, khususnya pada rumah tangga dengan pendapatan rendah (Akimov, Wijeweera, and Dollery 2006; Kenourgios and Samitas 2007; Levine 2003; D. Park and Shin 2015). Dengan begitu, rendahnya tingkat FII di Indonesia bisa jadi disebabkan oleh ketimpangan pendapatan. Oleh karena itu, penelitian merekomendasikan pengambil kebijakan untuk lebih fokus pada program pengentasan kemiskinan dan pembukaan cabang-cabang bank syariah di tingkat regional.
\end{abstract}

Kata kunci: 2 Dimension - Financial Inclusion Index (2D-FII), ketimpangan pendapatan, pengentasan kemiskinan, Bank Syariah 


\section{Introduction}

Organisation for Economic Cooperation and Development (OECD) reports that there is an evidence of rising gap between the rich and the poor in the last three decades in the OECD member countries which show that the richest 10 percent of population earn income 9.5 times higher than the lowest 10 percent and the Gini index also increased from 0.29 in the 1980 s to 0.32 in 2011. Indonesia also experiences a similar condition. Central Bureau of Statistics of Indonesia documents that the lowest coefficient value of the Gini index was 0.31 point, which occurred in 1999 . This value, however, slowly increased by about 0.1 point to 0.3 points every year and reached the highest level at 0.41 from 2011 to 2015. Latest data reports that the Gini index decreases by 0.1 point $(0.40)$ in 2016. Figure (1.1.) also clearly shows that on average Gini index in each province in Indonesia is still high, especially in Papua.

Figure 1. Gini Index in Each Province 2014-2015

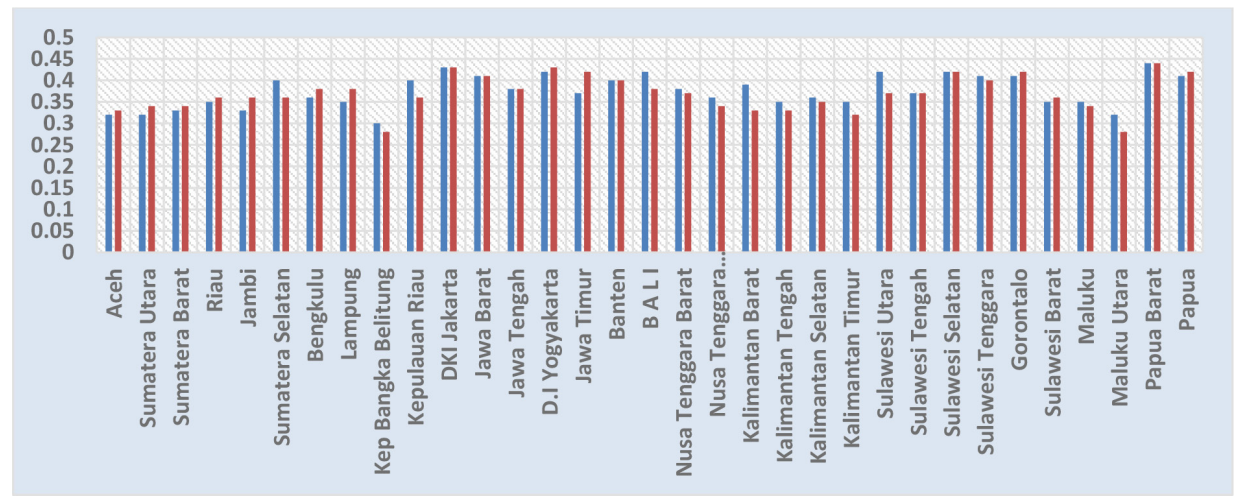

Sources: BPS. Authors' calculation

Table 1. Gini Index in Urban and Sub Urban Area in Indonesia

\begin{tabular}{cccc}
\hline Year & Urban & Sub Urban & $\begin{array}{c}\text { Urban }+ \\
\text { Sub Urban }\end{array}$ \\
\hline 2010 & 0.38 & 0.32 & 0.38 \\
2011 & 0.42 & 0.34 & 0.41 \\
2012 & 0.42 & 0.33 & 0.41 \\
2013 & 0.43 & 0.32 & 0.41 \\
2014 & 0.43 & 0.32 & 0.41 \\
\hline
\end{tabular}

Source: Statistic Bureau of Indonesia 
In addition, table (1.1) shows income inequality occurs both in urban and suburban areas. The coefficient value of the Gini index in urban areas is slightly higher than in suburban areas. Specifically, the difference value of the Gini index in urban and suburban areas is approximately 0.6 to 0.9 point. Graph (1.1) shows that from the mid-2013 to mid-2016, the percentage of poor people in Indonesia remains at average 8 percent and 14 percent in urban and suburban areas, respectively. Although, the value of Gini index in the urban areas is higher than in suburban (table 1.1. above), however, the percentage of poor people in a suburban area is almost double than in urban area. This indicates that, basically, the level of income in suburban areas is much lower than in urban areas. This indication can be traced from the reports of Central Bureau Statistics of Indonesia in 2015, i.e. between 2010 and 2014. The richest 20 percent of the population spent more than three times and two times than the poorest 40 percent in an urban and suburban area, respectively.

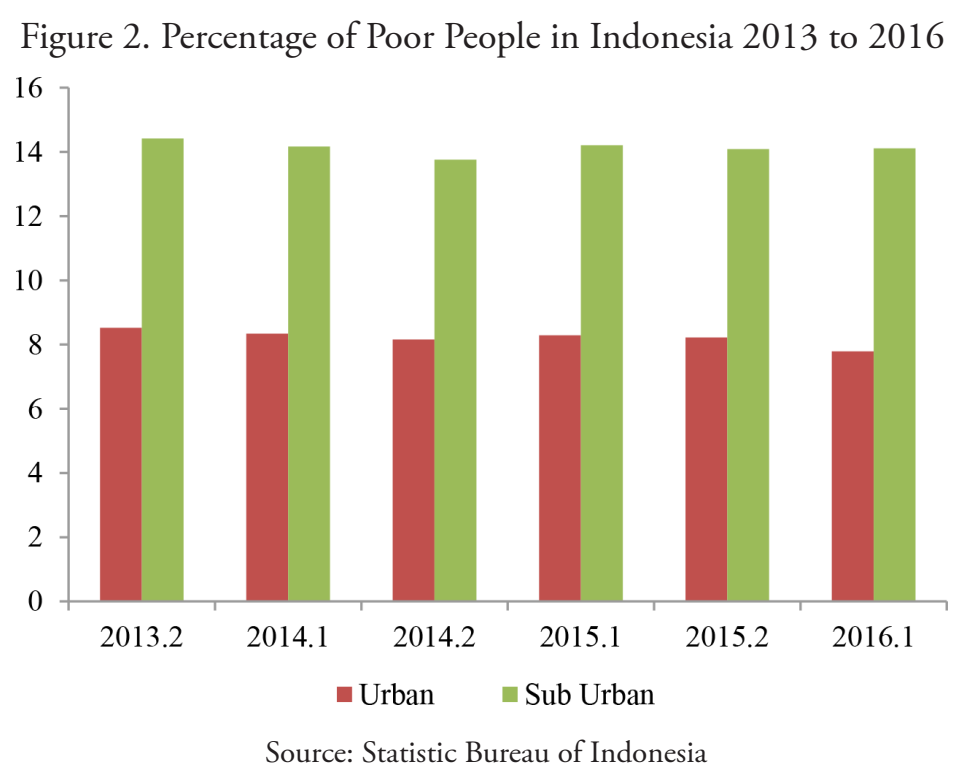

The consequences of high-income inequality are significant, which will not only affect the stability of the economy but also will threaten social security. Previous empirical evidence shows that the relationship between income inequality and crime is positive, which means that higher inequality causes more crimes and, thus, a loss in business ((Dadzie, Blanco, and Dony 2014; Fajnzylber 2002; Levitt 1999; Pshisva and Suarez 2010; Stolzenberg, Eitle, and Alessio 2006). As society 
is not stable, the investors will confront high risks, high crimes, and conflict areas. The urgency to minimize the gap of income is basically to stabilize the economy of a country. Previous research shows that income inequality is considered as the main determinant factor to create economic stability (Berg and Ostry 2011; Berg, Ostry, and Zettelmeyer 2012; Kumhof and Rancière 2010; Ostry, Berg, and Tsangarides 2014).

Previous empirical studies reveal that income inequality exists due to limited access to financial resources (Akimov, Wijeweera, and Dollery 2006; Kenourgios and Samitas 2007; Levine 2003; Park and Shin 2015). In other words, the financial sector may help to minimize the level of income inequality; that is by expanding its access, especially for the low-level income group. As more individuals can access to the financial sector, the level of financial inclusion will increase (Dabla-Norris and Kochhar (2015). World Bank (2015) further highlights that financial inclusion is an important factor in enhancing the welfare of the people. The greater level of financial inclusion is expected to minimize the level of income inequality and promote higher economic growth, employment, or even better health insurance.

In this regards, a high level of income inequality in Indonesia is, perhaps, caused by the low level of financial inclusion, even after islamic banking was firstly established in the 1990s. At this point, the establishment of the islamic banking system is basically to promote income and wealth distribution amongst individuals in society (Ismail 2010). Unfortunately, it seems that the benefit of islamic banks in Indonesia is accessed merely by a small percentage of Indonesian Muslims.

Considering this problem, there is a need to measure to what extent the level of financial inclusion of an islamic bank in Indonesia has been achieved. To do so, this research assesses the financial inclusion index (FII) introduced by Sarma (2008). FII is a multi-dimensional index which provides some financial dimension inclusive information within a single-digit number between 0 to 1 . A value of 0 means perfect financial exclusion, while the value of 1 means perfect financial inclusion. This index is plotted to see which region has a high and low value of financial inclusion. It is, thus, expected that the result of this research could be used for estimating the effectiveness of the financial inclusion strategy in islamic banks in order to reduce income inequality in Indonesia.

\section{Literature Review}

Financial inclusion index is firstly established by Sarma (2008). There are two fundamental objectives of financial inclusion index (FII) as explained by C. Park and Mercado (2015); Sarma (2012); and Yorulmaz (2013), i.e. (1) to estimate 
and monitor the level of financial inclusion and (2) to understand factors affecting financial inclusion. In addition, FII can also be utilized for cross country analysis and can be used to show the relationship between economic development and financial inclusion.

C. Park and Mercado (2015) develop financial inclusion indicators to investigate macroeconomic variable, which affects level or degree of financial inclusion in 37 countries within the Asian region. They find that income per capita, the rule of law, and demographic characteristic positively affect financial inclusion in developing countries in Asia. In addition, they also find that financial inclusion may reduce the level of poverty as well as income inequality contemporaneously. Yorulmaz (2013) develops financial inclusion indicators in the case of regional Turkey. He finds that income has a positive relationship with the degree of financial inclusion in each region in Turkey. That is, a higher level of income in such regions lead to a higher degree of financial inclusion, and vice versa.

Ardic, Heimann, and Mylenko (2011) measure access to financial services amongst World bank member countries by using CGAP database. They involve three elements, i.e., computing number of unbanked people, computing access to deposits as well as loans services, and measuring financial inclusion mandate in the member countries. The result shows that there is only 44 percent of adults who have access to financial services, and about 64 percent are unbanked people. It is also observed that there is one unbanked person in every five adults in developed countries. In addition, access to deposit services increased even during the global financial crisis in 2009.

In the case of India, Kumar and Mishra (2011) assess financial inclusion from the supply and demand side. The supply side or bank factors include several deposits, credit accounts, branches, average deposit, and amount of credit per account and credit utilized. Meanwhile, the demand side or household factors include saving, credit proposed to the bank, and insurance. The data is ranged from 2002-2003. The study also compares the compare the condition of financial service outreach in both rural and urban are. Empirical result shows that there is a significant difference in financial development among the state. The result shows that in the urban area of top state Chandigarh, the index of financial inclusion of banking outreach is six times higher than in another bottom area, Manipur.

In addition, there is also a significant gap amongst the rural area of the top state in Delhi and bottom state in Manipur; that is almost 8 times. It is observed that in the rural area, the outreach of financial services is low and, reversely, is high in the urban area. Meanwhile, financial inclusion index for households in the urban area $(0.29)$ is greater than in the rural area $(0.18)$. It is found that in the country 
level, only one person out of every three individual households has access to saving. Less than one person out of every five individual households has access for credit. Furthermore, in every eight individual households, only one person has insurance. In the rural area, only 25 percent and 20 percent of individual households have access to saving and insurance facilities from financial services, respectively.

\section{Data and Methodology}

Due to the availability of data, this research retrieves secondary data, i.e., 33 provinces cross-section data from 2014 and 2015. There are five groups of data involved in this research:

1. Total number of bank branches in each province

2. Total bank account volume in each province

3. Total third-party fund in each province

4. Total credit in each province

5. Gross regional domestic product (GRDP) each province.

All data are obtained from the Bank of Indonesia, the Financial Services Authority (Otoritas Jasa Keuangan, OJK), and the Central Bureau of Statistics (Badan Pusat Statistik, BPS). To measure FII, this research follows the work of Sarma (2008), with some adjustments depending on the provinces' condition. Basically, Sarma's work has similarities with the Human Development Index (HDI), the Gender-related Development Index (GDI), and Human Poverty Index (HPI) in its computation.

Figure 3. Dimension of Financial Inclusion Index

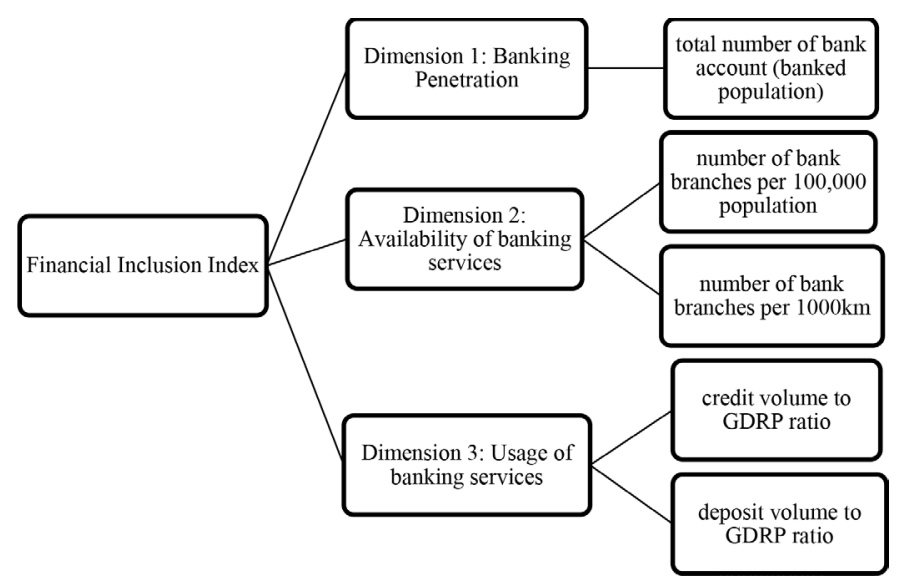


Figure (3.1) shows that FII consists of 3 dimensions, i.e., banking penetration, availability of banking services, and usage of banking services.

a. Dimension 1: Banking Penetration (BP)

Banking penetration measures the size of the "banked" population that is several people who have bank accounts.

b. Dimension 2: Availability of banking services (ABS)

The second dimension calculates the total number of bank branches per 100,000 people or ATM per 100,000 people and the total number of bank branches (per $1000 \mathrm{~km} 2$ ) of the population).

c. Dimension 3: Usage of banking services (UBS)

Usage of banking services is measured by the volume of credits, total deposits, gross domestic, and regional product (GDRP) ratio.

This research only uses two dimensions due to the unavailability of "banked population" data. To compute FII at the regional level, there are three steps of calculation.

First step: Computing Dimension index, $d_{i}$ for each dimension.

$$
d_{i}=\frac{A_{i}-m_{i}}{M_{i}-m_{i}}
$$

Notes:

$A_{i}=$ actual value from dimension $\mathrm{i}$

$\mathrm{mi}=$ minimum value from dimension $\mathrm{i}$

$\mathrm{Mi}=$ maximum value from dimension $\mathrm{i}$

Second step: Calculating FII with $n$-dimensional space for the $i$ country as follows:

$$
F I_{i}=1-\frac{\sqrt{\left(1-d_{1}\right)^{2}+\left(1-d_{2}\right)^{2}+\cdots\left(1-d_{n}\right)^{2}}}{\sqrt{n}}
$$

Third step: Calculating FII with 3dimensional space for province $i$.

In the third step, there is a need to identify a city or regional area by point $\left(\mathrm{BP}_{\mathrm{i}}, \mathrm{ABS}_{\mathrm{i}}, \mathrm{UBS}_{\mathrm{i}}\right)$ into three dimensions of Cartesian space, where $\mathrm{BP}_{\mathrm{i}}, \mathrm{ABS}_{\mathrm{i}}$, and UBS are dimension index, $d$ for province $i$ computed with equation (1). FII for province $i$ is measured by normalized inverse Eucthe lidean distance from point (pi ai,ui) and point $(1,1,1)$ becomes the best (or ideal) condition (perfectly financial inclusion) as follows. 


$$
F I I_{i}=1-\frac{\sqrt{\left(1-p_{1}\right)^{2}+\left(1-a_{i}\right)^{2}+\cdots\left(1-u_{i}\right)^{2}}}{3}
$$

The value of FII is between 0 and 1 . If FII equals 1 , it means that a province has ideal financial inclusion. Reversely, if FII equals 0 , it implies that a province has financial exclusion. Higher FII (close to 1) means a better condition of financial inclusion. From this FII formula, then we can categorize FII into three groups as follows:

$0.6<$ FII $\leq 1 \quad$ : high level of financial inclusion

$0.3 \leq \mathrm{FII} \leq 0.6 \quad$ : middle level of financial inclusion

FII $\leq 0.3 \quad$ : low level of financial inclusion

\section{Result and Discussion}

\section{Result}

\section{Dimension: Availability of Banking Services}

The existence of banking services is essential in the formation of financial inclusion. Indicators used for forming this dimension are the number of branches of the islamic Bank and Sharia Business Unit. Numbers of bank branches (per 100,000 populations) and the total number of bank branches (per $1000 \mathrm{~km} 2$ ) of the population are the indicators of the dimensions of this availability of banking services.

Accessibility to banking services by people is closely related to the number of bank branches. The existence of a large number of branch offices has not adequately described the extent of the spread of banking services. Thus, ABS dimension can be used to measure the public uses, extent deployment and affordability of banking services.

Table 2. Detail Value of ABS Dimension in 2014-2015

\begin{tabular}{|c|c|c|c|c|}
\hline No. & Province & 2015 & 2014 & Average \\
\hline 1. & Jawa Barat & 1.0000 & 1.0000 & 1.0000 \\
\hline 2. & Banten & 0.2843 & 0.2772 & 0.2808 \\
\hline 3. & DKI Jakarta & 0.7549 & 0.8614 & 0.8081 \\
\hline 4. & D.I Yogyakarta & 0.2059 & 0.2079 & 0.2069 \\
\hline 5. & Jawa Tengah & 0.7745 & 0.7822 & 0.7783 \\
\hline 6. & JawaTimur & 0.9020 & 0.9109 & 0.9064 \\
\hline
\end{tabular}




\begin{tabular}{|c|c|c|c|c|}
\hline 7. & Bengkulu & 0.0686 & 0.0693 & 0.0690 \\
\hline 8. & Jambi & 0.0686 & 0.0594 & 0.0640 \\
\hline 9. & Aceh & 0.2451 & 0.2475 & 0.2463 \\
\hline 10. & Sumatera Utara & 0.4020 & 0.3960 & 0.3990 \\
\hline 11. & Sumatera Barat & 0.1961 & 0.1980 & 0.1970 \\
\hline 12. & Riau & 0.1373 & 0.1584 & 0.1478 \\
\hline 13. & Sumatera Selatan & 0.1863 & 0.1980 & 0.1921 \\
\hline 14. & Bangka Belitung & 0.0196 & 0.0198 & 0.0197 \\
\hline 15. & Kepulauan Riau & 0.0980 & 0.0891 & 0.0936 \\
\hline 16. & Lampung & 0.1569 & 0.1683 & 0.1626 \\
\hline 17. & Kalimantan Selatan & 0.1373 & 0.1386 & 0.1379 \\
\hline 18. & Kalimantan Barat & 0.0980 & 0.0891 & 0.0936 \\
\hline 19. & Kalimantan Timur & 0.1863 & 0.1881 & 0.1872 \\
\hline 20. & Kalimantan Tengah & 0.0588 & 0.0594 & 0.0591 \\
\hline 21. & Sulawesi Tengah & 0.0392 & 0.0396 & 0.0394 \\
\hline 22. & Sulawesi Selatan & 0.2647 & 0.2574 & 0.2611 \\
\hline 23. & Sulawesi Utara & 0.0196 & 0.0198 & 0.0197 \\
\hline 24. & Gorontalo & 0.0000 & 0.0000 & 0.0000 \\
\hline 25. & Sulawesi Barat & 0.0098 & 0.0000 & 0.0049 \\
\hline 26. & Sulawesi Tenggara & 0.0490 & 0.0495 & 0.0493 \\
\hline 27. & Nusa Tenggara Barat & 0.1176 & 0.1287 & 0.1232 \\
\hline 28. & Bali & 0.0784 & 0.0792 & 0.0788 \\
\hline 29. & Nusa Tenggara Timur & 0.0098 & 0.0099 & 0.0099 \\
\hline 30. & Maluku & 0.0000 & 0.0000 & 0.0000 \\
\hline 31. & Papua & 0.0098 & 0.0099 & 0.0099 \\
\hline 32. & Maluku Utara & 0.0294 & 0.0198 & 0.0246 \\
\hline \multirow[t]{2}{*}{33.} & Papua Barat & 0.0000 & 0.0000 & 0.0000 \\
\hline & Indonesia & 0.2002 & 0.2040 & 0.2021 \\
\hline
\end{tabular}

Sources: OJK, BI. Authors' calculation

Value dimension of ABS in 2014 is about 0.2040 , while in 2015 is around 0.2002 . Value dimension of $A B S$ is very low, which equals $\leq 0.3$. Table (3.1) indicates that as many as 4 Provinces, i.e., Central Java, East Java, West Java, and DKI Jakarta have a dimension value of $0.6<\mathrm{ABS} \leq 1$ or high. The high value of the dimensions of $A B S$ because there is more than 40 number of bank branches in these four regions. In contrast, as many as 28 provinces have dimensional values $\leq 0.3$ or categorized as low financial inclusion. 


\section{Dimension: Usage of Banking Services}

The ratio of total deposit to provincial GDRP and the ratio of the total financing of islamic banks to GDRP are used to measure usage of banking services (USB) dimension. This dimension shows the level of banking services used by the public. The Province that is categorized as high-dimensional usability banking services is Bangka Belitung with the ratio of deposit and financing with GDP equals 11.48 (in 2014) and 11.85 (2015), respectively.

Table 3. Detail Value of UBS in 2014-2015

\begin{tabular}{clrrr}
\hline No. & \multicolumn{1}{c}{ Province } & 2015 & 2014 & Average \\
\hline 1. & Jawa Barat & 0.1746 & 0.1703 & 0.1725 \\
2. & Banten & 0.1995 & 0.2025 & 0.2010 \\
3. & DKI Jakarta & 0.0092 & 0.0111 & 0.0101 \\
4. & D.I Yogyakarta & 0.4714 & 0.4302 & 0.4508 \\
5. & Jawa Tengah & 0.0962 & 0.0897 & 0.0929 \\
6. & JawaTimur & 0.0931 & 0.0906 & 0.0919 \\
7. & Bengkulu & 0.2941 & 0.0033 & 0.1487 \\
8. & Jambi & 0.0013 & 0.0000 & 0.0006 \\
9. & Aceh & 0.1399 & 0.1109 & 0.1254 \\
10. & Sumatera Utara & 0.0276 & 0.0280 & 0.0278 \\
11. & Sumatera Barat & 0.1325 & 0.1401 & 0.1363 \\
12. & Riau & 0.0238 & 0.0210 & 0.0224 \\
13. & Sumatera Selatan & 0.0066 & 0.0072 & 0.0069 \\
14. & Bangka Belitung & 1.0000 & 1.0000 & 1.0000 \\
15. & Kepulauan Riau & 0.0322 & 0.0357 & 0.0340 \\
16. & Lampung & 0.1295 & 0.1151 & 0.1223 \\
17. & Kalimantan Selatan & 0.0333 & 0.0325 & 0.0329 \\
18. & Kalimantan Barat & 0.0024 & 0.0028 & 0.0026 \\
19. & Kalimantan Timur & 0.0021 & 0.0023 & 0.0022 \\
20. & Kalimantan Tengah & 0.0120 & 0.0068 & 0.0094 \\
21. & Sulawesi Tengah & 0.0010 & 0.0016 & 0.0013 \\
22. & Sulawesi Selatan & 0.0462 & 0.0478 & 0.0470 \\
23. & Sulawesi Utara & 0.0003 & 0.0007 & 0.0005 \\
24. & Gorontalo & 0.0012 & 0.0019 & 0.0016 \\
25. & Sulawesi Barat & 0.0005 & 0.0011 & 0.0008 \\
26. & Sulawesi Tenggara & 0.0016 & 0.0013 \\
\hline
\end{tabular}




\begin{tabular}{lllll}
\hline 27. & Nusa Tenggara Barat & 0.2417 & 0.2510 & 0.2464 \\
28. & Bali & 0.0052 & 0.0049 & 0.0051 \\
29. & Nusa Tenggara Timur & 0.0000 & 0.0005 & 0.0002 \\
30. & Maluku & 0.0006 & 0.0011 & 0.0009 \\
31. & Papua & 0.0013 & 0.0023 & 0.0018 \\
32. & Maluku Utara & 0.0882 & 0.0689 & 0.0785 \\
33. & Papua Barat & 0.0002 & 0.0007 & 0.0005 \\
& Indonesia & 0.0991 & 0.0874 & 0.0932 \\
\hline
\end{tabular}

Sources: OJK, BI. Authors' calculation

\section{Financial Inclusion Index: Regional Level}

As mentioned earlier, that financial inclusion index (FII) in this study is formed from the two dimensions, namely, ABS and UBS. FII in islamic banks in Indonesia is categorized as low, i.e., 0.1204 (2014), and increased to 0.1257 (2015). Table (3.3.) shows the average value of each dimension of financial inclusion achieved by Indonesia in 2014-2015. The average value of ABS and UBS are categorized as low, which equals 0.2021 and 0.0928 , respectively.

Table 4. Average Financial Inclusion Index Indonesia in 2014-2015

\begin{tabular}{cccc}
\hline \multirow{2}{*}{ Year } & \multicolumn{2}{c}{ Dimension } & FII \\
\cline { 2 - 4 } & UBS & ABS & 0,121 \\
2014 & 0,0874 & 0,2040 & 0,126 \\
2015 & 0,0991 & 0,2002 & 0,123 \\
Avarage & 0,0932 & 0,2021 & \\
\hline
\end{tabular}

Sources: OJK, BI. Authors' calculation

This study divides the value of the financial inclusion index into three categories, namely high $(0.6<\mathrm{IIK} \leq 1)$, moderate $(0.3<\mathrm{IIK} \leq 0.6)$, and low (IIK $\leq$ 0.3). Based on the value of financial inclusion index (Table 3.4), 84.8 percent or 28 provinces have a low index of the financial inclusion. There are five provinces has middle value of FII, i.e., West Java, with an average of 0.4146 , Central Java, with an average of 0.3394 , D.I. Yogyakarta, with an average of 0, 3176, Bangka Belitung with an average of 0.3068 , and East Java, with an average of 0.3541 . 
Table 5. Regional Level classification of Financial Inclusion Index in 2014-2015

\begin{tabular}{ccccc}
\hline & Criteria & \multicolumn{3}{c}{ Number of Provinces } \\
\cline { 3 - 5 } Category & $0,6<$ FII $\leq 1$ & 2014 & 2015 & $\%$ \\
\hline High & $0,3<$ FII $\leq 0,6$ & 5 & 5 & 15,2 \\
Middle & FII $\leq 0,3$ & 28 & 28 & 84,8 \\
Low & & 33 & 33 & 100 \\
Total & & & & - \\
\hline
\end{tabular}

Sources: OJK, BI. Authors" calculation

Table (3.5) below shows that the average FII for provinces in the eastern region (0.0406) is the lowest among the different groups of the province. The table shows that average FII for provinces in Java and Bali is the highest at 0.2846, followed by the provinces of Kalimantan and Sumatra 0.0635 to 0.0341 .

Table 6. Regional Level of FII in 2014-2015

\begin{tabular}{clccr}
\hline No. & Province & 2015 & 2014 & Average \\
\hline 1. & Jawa Barat & 0.416 & 0.413 & 0.415 \\
2. & Banten & 0.241 & 0.239 & 0.240 \\
3. & DKI Jakarta & 0.278 & 0.294 & 0.286 \\
4. & D.I Yogyakarta & 0.325 & 0.310 & 0.318 \\
5. & Jawa Tengah & 0.341 & 0.338 & 0.340 \\
6. & JawaTimur & 0.355 & 0.354 & 0.354 \\
7. & Bengkulu & 0.174 & 0.036 & 0.105 \\
8. & Jambi & 0.034 & 0.029 & 0.032 \\
9. & Aceh & 0.191 & 0.176 & 0.184 \\
10. & Sumatera Utara & 0.193 & 0.191 & 0.192 \\
11. & Sumatera Barat & 0.164 & 0.169 & 0.166 \\
12. & Riau & 0.079 & 0.087 & 0.083 \\
13. & Sumatera Selatan & 0.092 & 0.098 & 0.095 \\
14. & Bangka Belitung & 0.307 & 0.307 & 0.307 \\
15. & Kepulauan Riau & 0.065 & 0.062 & 0.063 \\
16. & Lampung & 0.143 & 0.141 & 0.142 \\
17. & Kalimantan Selatan & 0.084 & 0.084 & 0.084 \\
18. & Kalimantan Barat & 0.049 & 0.045 & 0.047 \\
\hline
\end{tabular}




\begin{tabular}{lllll}
\hline 19. & Kalimantan Timur & 0.090 & 0.090 & 0.090 \\
20. & Kalimantan Tengah & 0.035 & 0.033 & 0.034 \\
21. & Sulawesi Tengah & 0.020 & 0.020 & 0.020 \\
22. & Sulawesi Selatan & 0.148 & 0.146 & 0.147 \\
23. & Sulawesi Utara & 0.010 & 0.010 & 0.010 \\
24. & Gorontalo & 0.001 & 0.001 & 0.001 \\
25. & Sulawesi Barat & 0.005 & 0.001 & 0.003 \\
26. & Sulawesi Tenggara & 0.025 & 0.025 & 0.025 \\
27. & Nusa Tenggara Barat & 0.177 & 0.188 & 0.182 \\
28. & Bali & 0.041 & 0.041 & 0.041 \\
29. & Nusa Tenggara Timur & 0.005 & 0.005 & 0.005 \\
30. & Maluku & 0.000 & 0.001 & 0.000 \\
31. & Papua & 0.006 & 0.006 & 0.006 \\
32. & Maluku Utara & 0.058 & 0.044 & 0.051 \\
33. & Papua Barat & 0.000 & 0.000 & 0.000 \\
& Indonesia & 0.126 & 0.121 & 0.123 \\
\hline
\end{tabular}

Sources: OJK, BI. Authors' calculation

Figure 4. Average FII in Each Province 2014-2015

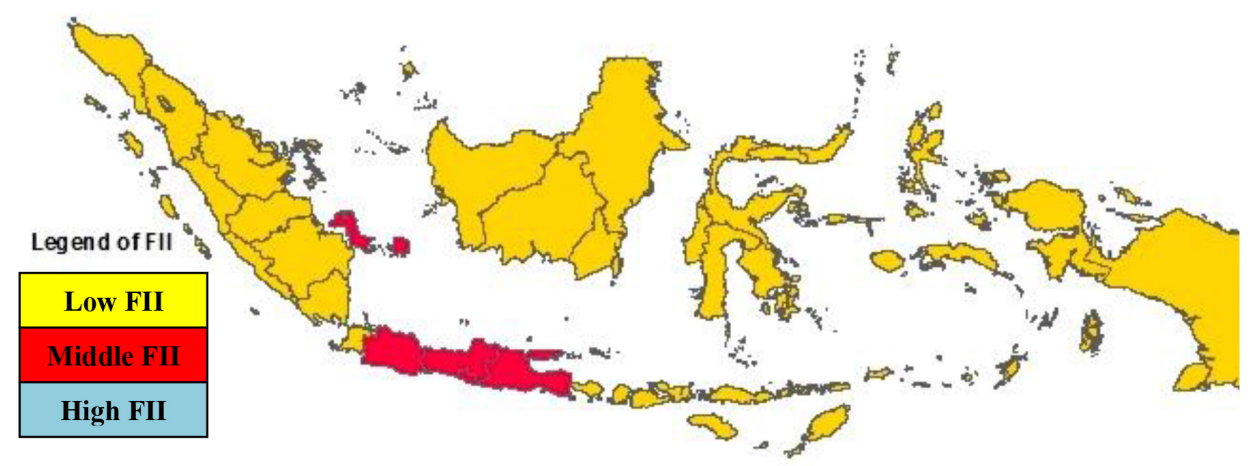

Sources: OJK, BI. Authors" calculation

The low value of the FII shows that the distribution and banking services in islamic banking by Indonesian people is still low. The difference between the value of financial inclusion across regional level shows that there is inequality access and usage of islamic banking services (Figure 4.) 


\section{Discussion}

This paper shows the fact that financial inclusion in Indonesia is not equally distributed amongst the region. It, thus, can be understood that if a large percentage of unbanked-people are individuals from dominated-Muslim countries (Mohieldin et al., 2012). Regarding this matter, this research offers two recommendations to promote financial inclusion for islamic banks in Indonesia and, hence, the problem of income inequality is expected to be minimized.

First, islamic bank should open new branches at the regional level, particularly in the eastern regions of Indonesia. One result of this paper shows that the availability of banking services (ABS) is low. Therefore, islamic banks should open new branches at the regional level to serve the financial needs of the people, especially of the poor. Previous research shows that one of the reasons why income inequality exists is because access to financial resources is limited (Akimov, Wijeweera, and Dollery 2006; Kenourgios and Samitas 2007; Levine 2003; D. Park and Shin 2015). Data from the World Bank shows that about 2 billion people around the world do not get any facility provided by the financial sector (World Bank, 2015).

Similarly, other previous studies address that one of the causes of income inequality in any country is limited access to the financial sector, especially for lowincome household (Akimov, Wijeweera, and Dollery 2006; Kenourgios and Samitas 2007; Levine 2003; D. Park and Shin 2015). Mohieldin et al. (2012) highlight that 73 percent of poor households are unbanked caused by the geographical situation or even they cannot afford its cost. However, the majority of them are Muslims. Moreover, this condition is worsened by the fact that all countries around the world deal with the problem of income inequality, including in Muslim-majority countries.

In practice, if islamic banks open new branches at the regional level, the entrepreneurs who try to expand their business may approach islamic banks. As the entrepreneurs expand their business, the quantity of production will increase and, hence, offer new jobs. In other words, there will be more people employed and thus minimizing income inequality.

Islamic banks, in this matter, should play this role in business reality, i.e., to serve the people, especially the poor. Ismail (2010) addresses that islamic banking and financial (IBF) system can bridge the gap between the haves and have-nots through the modification of the income distribution scheme. One main feature to distinguish islamic bank and the conventional bank is the prohibition of the interest rate in islamic banks. Islam condemns the practice of interest rate in the economy. Money capital in Islam is defined as an entitlement of a return if it is just to be borrowed by someone in a certain period. In other words, Islam does not recognize the interest rate as the price of time. This is because islamic teaching 
has an important role in the factor shares and functional distribution of income, which later affects the size of the individual income distribution. Thus, in Islam, someone cannot earn income by imposing interest rate. Reversely, Islam suggests the implementation of profit and loss sharing (PLS) system, which is believed to have an equitable system governing factor returns.

At this point, the islamic banking, in other words, is expected to: first, include the ability for the poor and all Muslim consumers to participate in, as well as, access the financial products and be included in the global economic order; and second, fill this gap by providing interest rate free products and services. Dabla-Norris and Kochhar (2015) argue that greater inclusive in finance will reduce income inequality and, hence, minimize the gap of income and develop resource allocation.

Many people live under the poverty line; while only a few live in abundant wealth. These poor people do not access islamic bank because they still fight to fulfil their basic needs and do not ask for financing because they do not have any enough collateral. Thus, there is a need to introduce zakat as a social security system and voluntary spending, which is expected to help poor people directly. The ultimate goal of zakat, such a social security system and voluntary spending, is to lift the dignity of the poor. In this regard, Islam highlights that every human being have equal opportunities, and thus, Islam does not consider social stratification in society. Pramanik (1997) underlines that social stratification classified based on wealth or social status will cause an obstacle to the growth of society. Conflicts amongst classes in the society will lead to instability in politics and economic condition. According to Ahmad (1991), the government must provide the basic needs of the people. Thus, zakat must be practised and be used to finance the social security system. If the amount of zakat is not enough, the government may use alternative financial resources.

In addition, Islam also strongly encourages Muslims to spend a certain portion of their income for the welfare of others, such as the needy and close relatives. Unlike zakat, the rate of voluntary spending is not determined. At this point, this research argues that to accelerate the life of the poor, the government should actively establish income redistribution instrument as the social security system, i.e., zakat.

\section{Conclusion}

Some points can be summarized as follows.

a. There are only four provinces that have a high value of the availability of banking services (ABS), i.e., Central Java, East Java, West Java, and DKI Jakarta. Recall that dimension of $\mathrm{ABS}$ is computed as the total number of bank branches per 100,000 people or ATM per 100,000 people and a total number of bank 
branches (per $1000 \mathrm{~km} 2$ ) of the population). Based on this result, it implies that the service of islamic banking is concentrated on Java Island. Meanwhile, Indonesia has a huge area which consists of 33 provinces and has five big islands (Papua, Kalimantan, Sumatera, Sulawesi, and Java). This result also implies that services of islamic banking in the other four islands are very low. Consequently, many Indonesian Muslims, until now, have probably not been familiar with islamic banking. This means that there is inequality access to islamic banking amongst one province to another province. On the other hand, this condition is contradictive with the fact that Indonesia has the largest Muslim population in the world; while only a small percentage of Indonesian Muslim who have access to islamic banking.

b. There is only one province, i.e., Bangka Belitung- that has high-dimensional usability of banking services (or Usage of Banking Services, UBS), measured by the total deposit to gross domestic, regional product (GDRP) ratio. This happens probably due to people in other province access islamic banks for financing purposes, instead of investment like in Bangka Belitung. Figure (3.2) also shows that income inequality in Bangka Belitung is considered as low, about 0.25 , and hence the people of Bangka Belitung have relatively equal income and tend to choose to invest their money in islamic banks. In addition, a limited number of islamic banks in other regions probably contributes to the low level of UBS in other provinces.

c. Twenty-eight provinces in Indonesia have a low index of financial inclusion. Meanwhile, five remaining provinces are categorized as the middle. It is noteworthy to highlight that the eastern regions of Indonesia have the lowest value of FII. This empirical result shows that there is a big gap of islamic banking services between western and eastern regions of Indonesia. Therefore, the high value of ABS can only be found on one island of Indonesia, i.e., Java (Central Java, East Java, West Java, and DKI Jakarta).

d. A large percentage of Indonesians live under the poverty line and do not access islamic bank because they still struggle to fulfil their daily life. Thus, there is a need to establish zakat as a social security system and voluntary spending.

Regarding these four main results above, policymakers should take action to encourage islamic banks to open new branches at the regional level, especially in the eastern regions of Indonesia. These new branches are to distribute financing to entrepreneurs in the regions so that they may expand their business. As is explained by Ismail (2010), islamic banking and financial (IBF) system can bridge the gap between the haves and have-nots through the modification of the income distribution scheme. In this matter, the spirit of financial inclusion 
and islamic banking are expected to serve the goal of islamic teaching on social justice, inclusion and resources distribution between the rich and the poor (Iqbal and Mirakhor, 2013). Kammer et al. (2015) elucidate that islamic banking is expected to promote greater financial inclusion, particularly for underprivileged Muslims. Promoting financial inclusion in islamic banking is argued to overcome the problem of inequality, especially for poor Muslim people in the long term. In addition, policymakers may take an urgent action to help the life of the poor by establishing formal islamic redistribution of income and wealth institution through zakat and voluntary spending.

\section{References}

Ahmad, Ziauddin. 1991. Islam, Poverty, and Income Distribution. The Islamic Foundation, Markfield Dawah Center.

Akimov, Alexandr, Albert Wijeweera \& Brian Dollery. 2006. Finance-Growth Nexus: Evidence from Transition Economies B.

Ardic, Oya Pinar, Maximilien Heimann \& Nataliya Mylenko. 2011. Access to Financial Services and the Financial Inclusion Agenda around the World: A Cross-Country Analysis with a New Data Set (English). Policy Research working paper; no. WPS 5537. Washington, DC: World Bank. http:// documents.worldbank.org/curated/en/519351468137108112/Access-tofinancial-services-and-the-financialinclusion-agenda-around-the-world-across-country-analysis-with-a-new-data-set

Athanassakos, George. (2009). "Value Versus Growth Stock Returns and the Value Premium: The Canadian experience 1985-2005.” Canadian Journal of Administrative Sciences 26(2): 109-121. (June, 2009).

Berg, Andrew \& Jonathan D. Ostry. 2011. "Inequality and Unsustainable Growth: Two Sides of the Same Coin?” International Monetary Fund StaffDiscussion Note: 1-21. http://www.imf.org/external/pubs/ft/sdn/2011/sdn1108.pdf\%5Cnhttp://d.

Berg, Andrew \& Jonathan D. Ostry, and Jeromin Zettelmeyer. 2012. "What Makes Growth Sustained?” Journal of Development Economics 98(2): 149-66.

Chan, Louis K.C \& Joseph Lakonishok. 2004. "Value and growth investing: Review and update(Review).” Financial Analysts Journal 60(1): 71-86.

Dabla-Norris, Era \& Kalpana Kochhar. 2015. Causes and Consequences of Income Inequality: A Global Perspective.

Dadzie, Christabel, Luisa Blanco \& Coline Dony. 2014. Study on Crime and Investment in Latin America and the Caribbean. USAID 
Eugene F. Fama \& Kenneth R. French. 2015. "A Five-Factor Asset Pricing Model." Journal of Financial Economics 116(1): 1-22.

Fajnzylber, Pablo. 2002. "Inequality and Violent of Crime *.” XLV(April).

Kammer, Alfred, Mohamed Norat, Marco Pinon, Ananthakrishnan Prasad, Christopher Towe, Zeine Zeidane \& an IMF Staff Team. 2015. "Islamic Finance: Opportunities, Challenges, and Policy Options." Islamic finance: $1-38$.

Kenourgios, Dimitris \& Aristeidis Samitas. 2007. "Financial Development and Economic Growth in a Transition Economy: Evidence for Poland.” Journal of Financial Decision Making 3(1): 35-48.

Kumar, Chandan \& Srijit Mishra. 2011. Banking Outreach and Household level Access: Analyzing Financial Inclusion in India. Retreived from http:// www.igidr.ac.in/conf/oldmoney/Banking\%200utreach\%20and\%20 Household\%20level\%20Access.pdf 